\title{
Beyond Asylum Claims: Refugee Protest, Responsibility, and Article 28 of the Universal Declaration of Human Rights
}

\begin{abstract}
Protests by refugees and asylum seekers have become of increasing interest to scholars of forced migration, citizenship and political theory in recent years for the critical potential inherent in such acts of protest to reconfigure conceptions of 'the political', 'the citizen', and refugees as voiceless, a-political victims. This paper turns to refugee and asylum seeker protest for a different reason. Rather than focusing on the act of protest, this paper turns to the substantive content of such protests. Exploring the claims and demands of refugees and asylum seekers in two long-running protest movements, in Austria and Germany, the paper argues that the protestors' demands encompass more than the claim to asylum, and can fruitfully be understood as UDHR Article 28 rights claims - claims to a social and international order for the realisation of human rights. The paper argues that these claims are not easily addressed by existing approaches to responsibility for forced migration, and turns instead to Iris Marion Young's conception of political responsibility for structural injustice as a potentially promising framework.
\end{abstract}

Keywords: refugees; protest; human rights; responsibility; Iris Marion Young

\section{Introduction}

Recent years have witnessed a proliferation of coordinated protest movements of refugees and asylum seekers across Europe. They began in Germany, in 2012, and have spread to Austria, Belgium, Bulgaria, Denmark, France, Greece, Italy and the Netherlands, as well as to states on the periphery of the EU. ${ }^{1}$ Each protest was sparked by specific conditions on the ground, and they vary in size and tactics, but they all make concrete demands for better living conditions, contest the legal, political and economic exclusion of asylum seekers and irregular migrants from European society, and contest the withholding and withdrawal of rights. The protestors are mainly asylum seekers - both with pending claims for recognition under the Refugee Convention and with claims that have been denied - and their actions have spurred campaigns of citizens, recognised Refugees, and documented migrants across the continent in solidarity. 
Protest movements by irregular migrants have become of concerted interest to scholars of citizenship, largely because of the potential inherent in such acts to challenge and to reconfigure conceptions of 'the political', 'the citizen' and of forced migrants as voiceless, apolitical subjects. ${ }^{2}$ While this approach to refugee and asylum seeker protest is one that the author of this paper shares elsewhere, ${ }^{3}$ this paper turns to the protests for a different reason. Rather than the act of protest, it argues that important insights into challenges of human rights protection and questions of responsibility for forced migrants can be gained by focusing instead on their substantive content: the claims and demands made.

Analysing the press releases, statements, letters, and videos made available by protesting refugees and asylum seekers in Austria and Germany on a series of blogs and social media pages that they maintain, the paper examines the claims for rights and recognition, and of responsibility, that the protestors make. It argues that they demand recognition of their status as refugees, human beings and rights bearers, the protection of their human rights, and claim that the global North bears a responsibility for the protection of these rights which is grounded in the socio-political and economic structures of global politics. In making these claims and demands the protestors do much more than claim asylum. They act as, in the words of one of the protestors in Germany, "whistle-blowers": not just of failures or abuses in their states of origin, as their requests for asylum indicate, but of the political and socio-economic structures of global life, and of the everyday implication of ordinary citizens in them. ${ }^{4}$ In drawing attention to the flaws inherent in the international refugee regime and international human rights regime, themselves grounded in the very structure of international life, the protestors present a challenge not only to address their individual claims for recognition and rights - their asylum claims - but the very processes and structures that continue to prevent human rights being a reality of lived experience for growing numbers of people. Their claims are, thus, not simply for admittance as exceptions to an otherwise well-functioning status quo, but are, rather, 
claims that the status quo itself is untenable and needs to be addressed. Such claims are at root, this paper argues, claims to an often forgotten human right: Article 28 of the Universal Declaration of Human Rights, which states that "Everyone is entitled to a social and international order in which the rights and freedoms set forth [in the UDHR] can be fully realised." 5

The paper is structured as follows. The first section explains the purpose and contribution of the paper, situating it at the nexus of scholarship on human rights, forced migration, and political theory. The second section then examines two instances of refugee protest, in Germany and Austria, highlighting the different claims and demands made. Beginning at roughly the same time, these two protests provided the catalyst for protests that have followed elsewhere in Europe. They have also been the largest and have the most established online presence, which the protestors use to communicate not only with members of the movement but also with potential supporters and the wider community, providing an easily accessible source to understand the claims and demands that the protestors make. The third section introduces Article 28 of the UDHR and examines why a right which seems on the surface to have little to do with forced migration can, in fact, usefully be understood as central to the claims and demands made by the protestors. The fourth section then explores the questions of responsibility raised by the protestors and by interpreting their claims and demands as Article 28 rights claims. It will be argued that these claims raise important questions with which scholars of forced migration, human rights, and political theory should engage, and that Iris Marion Young's conception of political responsibility for structural injustice provides a potential framework within which to do so. It will be concluded, however, that such an approach to addressing the claims and demands of the protestors cannot do without the cultivation of solidarity within and across borders, and that this is where the particular power (potential) of refugee protest movements lies. 


\section{Responsibility for forced migrants and their human rights:}

Scholarship on human rights, forced migration, and political theory has developed along largely separate tracks since the signing of the UDHR in 1948, the Convention Relating to the Status of Refugees in 1951, and the publication of John Rawls' A Theory of Justice in 1971. Links have been drawn between human rights and global poverty, but such work has tended not to focus on the issue of refugees and asylum seekers. ${ }^{6}$ Dialogue between human rights law and international refugee law is increasingly common, but tends to be restricted to points of law and questions of influence, rather than addressing questions of justice. ${ }^{7}$ There is a wellestablished debate on whether duties of justice or humanitarianism are owed to refugees, but these debates have been limited in a number of ways, outlined below, and rarely address broader human rights questions beyond the provision of physical asylum. This article is a modest, and limited, attempt to show how these three fields are, and should be recognised as, intimately connected, and takes as its point of entry the vexed question of responsibility for the protection of forced migrants. ${ }^{8}$

Responsibility for forced migrants has been conceptualised rather narrowly, and tends to fall into one of two paradigms. The first is that of state obligations under international refugee law. ${ }^{9}$ Responsibility, in this framework, is understood primarily in legal terms, and relates to obligations incumbent upon states under the refugee regime. Such legal responsibilities are minimal, being limited to a responsibility not to return any individual to a state where her life or freedom would be threatened on the grounds of race, religion, nationality, membership of a particular social group or political opinion, but with no corresponding duty to grant asylum to those who seek it. Burden-sharing is an important principle in the refugee regime, but this has not been translated into any formal legal obligations. 
The second paradigm of responsibility is more firmly entrenched within normative political theory and can be characterised in broad terms as a debate over the ethics of admission: when, if at all, and in relation to whom, state controls on immigration are permissible. Whether such work is concerned with refugees and asylum seekers specifically, or with the ethics of migration more generally, the question of responsibility tends to be state-centric in its focus. Walzer and Miller, for example, each take the rights of states to control their borders as the starting point for thinking through what responsibilities states might have toward foreign nationals seeking admission. For Walzer, the right to maintain "communities of character" restricts the duties of states to the principle of mutual aid, permitting a state to refuse entry to needy foreigners where the "character" of the community may be threatened. ${ }^{10}$ Miller grants to refugees the right to temporary sanctuary and aid, but the state's right to self-determination may justify the exclusion of refugees, and certainly justifies the exclusion of other nonnationals. ${ }^{11}$

The majority of work on the ethics of admission portrays the state, further, as the only relevant bearer of responsibility: the question at hand is overwhelmingly the obligations or responsibilities of states. To a certain extent, this focus is justified. Whether or not globalisation will render the state obsolete in the future, it is still currently the case that states retain the power to decide who may cross their borders, and on what terms, and asylum requests are made of the state, not any other sub-national or trans-national actor. However, as has been argued by the emerging field of Critical Citizenship Studies, the state is neither the only, nor always the primary, community of belonging of influence and importance in global politics, nor of the politics of rights or migration. ${ }^{12}$ As McNevin has ably shown, non-citizens occupy various positions within the contemporary neoliberal state with which traditional debates in normative political theory have been reluctant thus far to adequately engage. ${ }^{13}$ None of this is an argument 
for dispensing with the state in attempting to think through responsibility for the protection of forced migrants. It is, however, an argument against an exclusive focus on the state.

In addition to their state-centric nature, these debates also tend to proceed on the basis of abstract thought experiments, on the one hand, or an understanding of the "generic" refugee, on the other, rather than the concrete experiences and claims of forced migrants themselves. Refugees are often represented in a rather superficial, one-dimensional way, reducing them to a single act and utterance - the request for admission and physical security - and in which clear distinctions can, or should, be made between "political" and "economic" reasons for such a request. Broader questions of responsibility for human rights protection tend to be bracketed off, and focus given to the responsibility to provide physical asylum. This is not to say that abstract thought experiments - such as determining obligations to the needy stranger by way of analogy with the drowning child in the river - have no value in theorising, nor that the request for admission is not an important aspect of forced migrants' need for rights protection. But what is sacrificed in pursuit of this abstraction or this simplification? And do political theorists run the risk of producing accounts of responsibility for protection that are logically coherent on their own terms, but which fail to correspond to the reality on the ground? These are the questions that motivate this article. Its purpose is not to contribute to the debates above on their own terms but, rather, to make an intervention into the broader issue of responsibility for protection of forced migrants by taking a different starting point altogether, thereby questioning the state-centric assumptions underpinning these debates, and by bringing human rights more squarely into focus. As such, this paper takes its cue not from normative political theory, but from Critical Citizenship Studies, and from its analyses of the emerging phenomenon of refugee and asylum seeker protest movements.

Protests by irregular and non-status migrants, including refugees and asylum seekers, have become of concerted interest to scholars of citizenship, largely because of the potential 
inherent in such acts to challenge and to reconfigure conceptions of 'the political', 'the citizen' and of forced migrants as voiceless, apolitical subjects. McNevin analyses how the political action of irregular migrants in France, the USA and Australia not only seek the extension of formal status, but also challenge the national and racial notion of citizenship in modern politics, and how, through their (unauthorised) actions, they rupture the very conceptual vocabulary that polices the boundaries of political belonging. ${ }^{14}$ Similarly, Nielsen and Isin argue that these movements of 'non-citizens' necessitate a complete rethink of our conceptual vocabulary and understanding of citizenship. Rather than a legal status that one possesses or is granted, citizenship is a performative practice that one enacts. ${ }^{15}$ Rather than focusing on the act of protest, however, this paper argues that important insights into questions of responsibility for the protection of the human rights of forced migrants can be gained by focusing instead on their substantive content: the claims and demands made. The focus of this paper thus diverges from that of Critical Citizenship Studies scholars, but the foundation of the analysis remains the same: what happens to understandings of core institutions and practices in the politics of migration if the analysis begins from the actions and voices of the migrant?

Since migrants, particularly those lacking secure status or authorisation for their movement, live in a situation of precarity, there are a great many structural obstacles in place to prevent or disincentivise their speech and action in the public sphere, not least the fear of deportation or imprisonment. This makes theorising from their perspective a challenging, but not impossible task. Protest movements present an opportunity to engage with the voices and actions of forced migrants, as the purpose of such protests is precisely to make their concerns and wishes known to a wider audience than the civil servants charged with evaluating their asylum claims. However, the question of representativeness then inevitably arises. It may not be possible to discern with any real "accuracy" how representative the claims and demands of those involved in protests are of the wider group, since even so simple a measure as the 
numbers involved could be misleading. But the view taken here is that it is not necessary for such claims to be representative of all refugees and asylum seekers in order for them to present questions about responsibility and global human rights protection that are worth addressing; and it is to these questions that this paper now turns.

\section{Refugee and Asylum Seeker Protest - "We demand our rights!"}

Asylum seeker protest has been a feature of German politics for roughly twenty years, ${ }^{16}$ but the protest movement was reinvigorated in 2012, in response to the suicide of a 26 -year-old Iranian asylum seeker, Mohammed Rahsepar, who had been held in a detention centre in Würzburg. In the months following his death, asylum seekers and recognised Refugees set up protest camps in various cities across Germany and, in September 2012, asylum seekers, Refugees and supporters began a $600 \mathrm{~km}$ march to Berlin and established a protest camp in Orianenplatz. ${ }^{17}$ Hunger strikes, protest marches, and Refugee Liberation Bus Tours, coordinated under the umbrella of Refugee Tent Action, have occurred across Germany in the years since. The protestors demand: the abolishment of the Residenzpflicht, which prohibits asylum seekers from leaving the district in which they have been registered for any reason without permission; a halt to all transfers under the EU's Dublin Regulation; the erasure of their fingerprints from the European identity database, EURODAC, which contains the fingerprints of asylum seekers and irregular migrants to facilitate Dublin deportations; improvements to conditions inside asylum accommodation centres; the regularisation of Germany's 'tolerated' asylum seekers, whose claims for protection have been refused but who cannot be deported, and who therefore exist in Germany without secure legal status and rights; and a recognition of all asylum seekers as Refugees, arguing that all reasons, including socioeconomic, that compel a person to leave his/her country of origin are, ultimately, political. ${ }^{18}$ 
On November 24, 2012, in Austria, approximately one hundred asylum seekers and their supporters marched the $35 \mathrm{~km}$ from the refugee reception centre in Traiskirchen to the centre of Vienna, and erected a Refugee Protest Camp in front of the Votive Church in Sigmund Freud Park. The camp remained in the park until it was broken up by the police on December 28,2012 , at which point the protestors were welcomed into the church itself to maintain their camp. In March 2013, the protestors were invited to relocate to the Serviten Monastery, where they remained until the end of October that same year. ${ }^{19}$ Deteriorating conditions of detention for asylum seekers had provided the initial catalyst for the protests, but the protestors' demands went beyond improved detention conditions. They demanded: that they be granted the right to remain in Austria or, at the very least, to have their fingerprints deleted from EURODAC should Austria decide to deport them; that they be granted the right to work, as they wished to sustain themselves rather than rely on the state, ${ }^{20}$ basic support for asylum seekers in Austria regardless of status; an end to enforced internal transfer to isolated rural areas; access to employment, educational institutions and social security; a halt to all Dublin deportations; the establishment of an independent review and appeal authority for asylum applications; and the recognition of the validity of socio-economic motives behind refugee flight. ${ }^{21}$

In addition to these concrete demands, the statements given by the protestors in press releases, interviews and press conferences reveal three kinds of broader inter-related claims: claims for rights, and claims for status/recognition, addressed below, and claims of responsibility, to be addressed later.

\section{Claims for rights}

The demands that the protestors made of Austrian and German authorities - for freedom of movement, choice of residence within Germany and Austria, access to education and employment, and basic social support - are all appeals to the authorities to respect the 
protestors' human rights. The protestors in Germany linked their actions specifically to repeated violations of their human rights by the German authorities: "following a long tradition of refugee struggles against the violation of our human rights, we set up the Refugee Protest Camp at Orianenplatz..."22 Both protest movements framed their actions explicitly in rights language, both in the demand for recognition of specific rights (freedom of movement, access to education, and so on), and in framing those demands in terms of the Universal Declaration of Human Rights. In the Austrian protests, for example, the protestors held a press conference as they established their camp, in which they specifically referenced Article 2 of the UDHR which prohibits discrimination in regard to the provision and protection of human rights - both as justification for their actions, and as an indictment of Austrian asylum policies which use the protestors' (lack of) legal status as a reason to deny access to these supposedly human rights. ${ }^{23}$ The protestors in Germany claim not only that their rights have been "stolen" 24 but that this theft has been effected by the law itself:

The conditions in which refugees live are excluding [...] because states with economic and nationalist interest are capable to write laws against refugees and migrants which violate human rights. The same human rights that they have written and signed: the prohibition of freedom of movement, the banning of the right to free choice of residence and the banning of social participation, for example, participation in elections, etc., which have become law $[\ldots]$ This is the open contradiction to human rights. This means that a refugee and/or migrant who is not from here has not the same human rights as a citizen of this country. ${ }^{25}$

Paradoxically, perhaps, the rallying cry of the Austrian protestors, "We demand our rights!" positions the rights being demanded as those the protestors already possess: "We demand our rights!" Though this might appear to be simply an example of linguistic confusion, this is, rather, what Judith Butler refers to as a 'performative contradiction'. When a disenfranchised group make a universal demand, they lay claim to something from which they have been constitutively excluded. ${ }^{26}$ In doing so, they draw attention to the injustice of being denied 
something that is supposed to be theirs. To draw attention to this exclusion is to reveal that the 'universal' upon which these rights depend - human status - is not in fact, in its present configuration, a universal at all. The performative contradiction of demanding their rights draws attention to the extent to which the universal - human - rests upon the particular and exclusionary - legal status.

\section{Claims for status/recognition}

In demanding respect for their human rights, and the recognition of the validity of a broader range of causes of flight for recognition as a Refugee, the protestors make a claim for recognition of legal status as rights holders. Article 1A(2) of the Refugee Convention defines a Refugee as a person who:

[...] owing to a well founded fear of being persecuted for reasons of race, religion, nationality, membership of a particular social group or political opinion, is outside the country of his nationality and is unable or, owing to such fear, is unwilling to avail himself of the protection of that country $[\ldots]^{27}$

Within the EU, protection is, in theory, available to some forced migrants who do not meet the criteria of Article 1A(2). Under Article 15 of the Qualification Directive, Subsidiary Protection can be granted to those who would face any of the following if they were returned to their country of origin: the death penalty or execution; torture or inhuman or degrading treatment or punishment; or "serious and individual threat to a civilian's life or person by reason of indiscriminate violence in situations of international or internal armed conflict." 28

The protestors' call for the recognition of socio-economic drivers of flight as valid for recognition as a Refugee are, thus, a claim for a formal legal status which would provide access to the protection of their human rights. Neither the Refugee Convention, nor the Qualification Directive explicitly provide for the extension of international protection to those fleeing serious violations of, or failures to protect, socio-economic rights. Foster and Hathaway have both 
demonstrated how a claim for Refugee status based upon persecution which manifests as severe violations of socio-economic rights could be successful, but they have also highlighted two fundamental obstacles. The first is that such claims will automatically fail if the persecution which manifests as violations of socio-economic rights cannot be linked with the applicant's race, religion, nationality, political opinion, or membership of a particular social group. The second obstacle is that even claims with an economic element which can demonstrate such a connection are often denied on the basis of a deeply ingrained, but highly problematic, assumption that socio-economic drivers of flight make an individual an 'economic migrant' rather than a refugee. ${ }^{29}$ This means that deliberate violations of human rights, or the inability of one's state of origin to protect them, may be evidence of the need for international rights protection, but this protection is in practice only provided for through acquiring Refugee status or, in the EU, Subsidiary Protection status. This is, however, easier said than done. ${ }^{30}$

The majority of the concrete demands made by the protestors can be addressed within the existing bounds of the refugee protection regime - such as improved conditions for asylum seekers while their claims are examined, freedom of movement within Austria and Germany, the right to work, access to education, and so on. The broader claims that they make, however, cannot be so accommodated as they target the very foundations and boundaries of the regime itself, and speak to broader human rights obligations. But even here, the claims and demands of the protestors push the boundaries. Their claims signal not just toward existing human rights obligations beyond the narrow confines of the refugee regime, but toward a broader understanding of human rights obligations in general. In highlighting and contesting the role that legal status plays in the ability to enjoy one's human rights in practice - by circumscribing the extent of any given state's human rights obligations to an individual - the protestors put forth an understanding of human rights as a shared responsibility of all states and people to ensure. ${ }^{31}$ Human rights, on this understanding, are not simply the responsibility of one's state 
of origin and only, in exceptional circumstances - i.e. meeting the stringent criteria of an existing legal exception - the responsibility of another state. In other words, rather than conforming to the rules of the current system of refugee and human rights protection, premised upon communalist (read, state-based) understandings of responsibility and rights, the protestors challenge the continued validity/justice of this system, and in this sense can fruitfully be understood as Article 28 rights claims.

The entitlement to a social and international order for the realisation of human rights

\section{Article 28 of the UDHR}

Article 28 of the UDHR declares that "Everyone is entitled to a social and international order in which the rights and freedoms set forth in this Declaration can be fully realised." The article was introduced during the drafting process by the Lebanese member of the Commission on Human Rights, Charles Malik, as he felt that it was insufficient merely to enumerate rights without also stipulating that "society itself should be of such a nature as to ensure the observance of those rights." 32 His original proposal had spoken of the 'right' to a social and international order, rather than an 'entitlement to', and the amendment of the language appears to have been suggested for purely stylistic reasons to avoid the repetition of the terminology of rights. ${ }^{33}$ This proposal encountered little opposition and the provision as a whole was adopted with minimal debate.

Article 28 is not explicitly reproduced in either of the binding International Covenants opened for signature in 1966 - on Civil and Political Rights (ICCPR) or on Economic, Social and Cultural Rights (ICESCR). However, both the Preamble of the ICCPR and ICESCR, and Article 2(1) of the ICESCR reproduce the spirit of Article 28 in noting that conditions need to be created, through international assistance and cooperation, to enable the enjoyment of 
rights. ${ }^{34}$ Despite the lack of explicit reproduction in the binding Covenants, the importance of Article 28 has been recognised by the United Nations, most notably in providing the intellectual basis for the right to development. It is explicitly referenced in the 1986 Declaration on the Right to Development, which highlights that "efforts at the international level to promote and protect human rights should be accompanied by efforts to establish a new international economic order." ${ }^{35}$ Article 28 has also been referenced by the Committee on Economic, Social and Cultural Rights, which monitors the implementation of the ICESCR, noting the problem of structural obstacles to the eradication of poverty - such as unsustainable foreign debt and an unbalanced financial and trade system - which must be addressed if national anti-poverty struggles are to be sustainable. ${ }^{36}$ Outside of the context of development and poverty reduction, however, Article 28 does not seem to have made much of a lasting impression, or at least not explicitly. In academic literature on human rights it has been largely forgotten, with a handful of exceptions, most notably Thomas Pogge, who uses it to ground his institutional understanding of human rights.

In making reference to the rights and freedoms set forth in the UDHR, Article 28, Pogge explains, addresses the concept of a human right: "they are to be understood as claims on the institutional order of any comprehensive social system." 37 Article 28 implies that social systems ought to be structured to allow for the fullest possible realisation of human rights, allowing for judgments of the moral quality, or justice, of social systems based on the extent to which they succeed in affording to all their participants secure access to the objects of their human rights. ${ }^{38}$ For Pogge, a negative duty of justice is violated when an institutional order avoidably fails to realise human rights, and those responsible for addressing such violations are those of its members who significantly collaborate in its imposition. ${ }^{39}$ On this account, human rights are both claims on an institutional order and against those who collaborate in its imposition, adding another dimension to the 'universality' of human rights. Under this 
expanded understanding, human rights are universal not only in the sense that all individuals are entitled to them by virtue of their human status, but also in the sense of having global normative reach: "human rights give persons claims not merely on the institutional order of their own societies, which are claims against fellow citizens, but also on the global institutional order, which are claims against their fellow human beings." ${ }^{40}$ What Article 28 is therefore asking of citizens and governments is that they support, and work toward, institutional reforms of the global order so that it not only supports the emergence and stability of rights-respecting regimes, but that radical economic deprivations and inequalities, which impact on states' abilities to protect human rights, are reduced. ${ }^{41}$ Stephen Marks is of the same view when he highlights the "revolutionary proposition" inherent in Article 28: that everyone has a right to a "radical change in power relations both domestically and internationally, for no political economy or legal system on earth today adequately ensures all human rights for everyone, and the structures of the international system often inhibit their enjoyment." ${ }^{, 42}$

Pogge's claims about the unjust nature of the institutional order, and of the responsibilities of citizens for that order have both been subject to critique, particularly within the vast literature in political theory on the nature and scope of justice. Even an overview of these debates is beyond the scope of this article, but there are two critiques in particular which warrant mention here. While the role played by the structure of global political and economic life in producing conditions of poverty and catalysts for forced migration is becoming a less controversial position, as briefly examined later in this article, there is still academic debate over whether or not such a situation gives rise to claims of justice and responsibility, rather than merely of charity and humanitarianism, and what actions such claims require. For some, what matters most for whether or not duties of justice are owed to the global poor is that an institutional order is designed to provide reasonable opportunities for societies to raise themselves out of poverty, rather than whether or not such an order foreseeably enables and 
incentivises harm to others. Since some societies have managed to develop economically, and relatively quickly, it is not immediately clear that the current order is not like that. ${ }^{43}$ Perhaps more problematic than the question of whether duties of justice are owed to the global poor in Pogge's account, however, is his attribution of causal responsibility to the citizens of western states, merely by virtue of their involvement in government - via voting or paying taxes. ${ }^{44}$ Are paying taxes and voting really actions that can, or should, be characterised as "significantly collaborating" in the imposition of an unjust order that their governments (re)produce? Moreover, Pogge does not adequately explain why it is only citizens of affluent countries that appear to bear this responsibility. As Debra Satz points out: "Is a laid-off American steelworker, for example, really more responsible for global poverty than a rich citizen of a poor country?"45 These critiques of citizen responsibility inform the development of Iris Marion Young's political responsibility model, addressed below, by engaging with the question of the responsibility of individuals in relation to the global institutional order not on the basis of which state they are citizens of, but on their social positions in relation to such injustice - how much power, privilege, interest or collective ability any individual, or group of individuals possess in relation to such injustices.

It would be tempting to read both Pogge and Marks as advocating a responsibility for addressing the consequences of the global structural order that it would only be possible to discharge by completely removing oneself from all participation in that order. However, neither Marks nor Pogge advocate this position. Rather than simply discontinuing all participation in such a social and international it is better, Pogge argues, for victims of the injustices that the order produces if "we continue participation while also working toward appropriate institutional reforms or toward shielding those victims from the harms we also helped to produce. ${ }^{" 46}$ In other words, that long-term reform efforts and short-term human rights-based protection efforts are engaged in, in pursuit of an international order that more adequately 
protects human rights for all. Returning to the claims and demands made by the protesting asylum seekers in Austria and Germany, and in particular to their claims of responsibility, it can perhaps now be seen how and why their claims can be understood as Article 28 rights claims.

\section{Protestors' demands as Article 28 rights claims}

To the author's knowledge, the protestors themselves have not explicitly invoked Article 28 of the UDHR during their protests. However, in what follows, it is suggested that their claims and demands resonate very strongly with Article 28, and that Article 28 can be a useful framework for understanding and engaging with these claims and demands.

Both protest movements framed their claims for rights and recognition within continental and global socio-economic processes. The refugee regime, and European asylum policy, attempt to maintain a strict separation between 'political' and 'economic' reasons for leaving one's country of origin, recognising only 'political' reasons - and then only those covered by the nexus clause - as valid for recognition as a refugee. This distinction, or the attempt to maintain it, is based upon the assumption that migration on the basis of economic considerations is 'voluntary' but migration on the basis of political considerations is 'involuntary'. This distinction, for the protestors, is untenable for two reasons: first, political and socio-economic conditions cannot be so arbitrarily divided, as has been consistently demonstrated by forced migration scholars elaborating the migration-asylum nexus ${ }^{47}$ and second, such separation serves as a tactic for affluent - especially former colonial - states to absolve themselves of responsibility for addressing the consequences of their cumulative foreign and economic policies. One example of this view is evident in the following statement, issued by a protestor, Arash, upon his arrest for violating the Residenzpflicht, in Munich in January 2014: 
The reasons for flight and migration are: dictatorships, poverty, oppression and war. Those causes, forcing people to flee, have their roots in the mutual relations between countries of origin and destination [...] [and] formed in this globalised economic system and the resulting distribution struggles over resources and power. The resulting imbalance is the main reason for displacement and migration. The existence of this system is made possible by a network of neo-colonial exploitation and oppression. That circuit is formed by both the 'democratic' and/or 'liberal' states, and maintained by dictatorial states. In countries such as [...] Iran and Pakistan, the system is protected with a visible state violence. In countries such as Germany and France, the same system is protected with 100 billion Euros of arms exports. ${ }^{48}$

In drawing attention to the links between European social, economic and military policies, and the situations from which they have fled, the protestors seek to ground their claims for rights beyond the criteria of the Refugee Convention by foregrounding the interconnected nature of global economics and politics and its impact on their ability to enjoy their human rights. In a press release explaining why they initiated the protests, the members of Refugee Tent Action stated that:

The struggle against the capitalist isolation system is an important fight for our future. We do not want to live in refugee camps, in which we are isolated. We do not want to be victims of racist measures [...] We want to connect our struggle with all anti-capitalist and anti-fascist forces, with all our comrades in the streets of the world. We do not want to pay the bill for the wars and crises of the capitalist-imperialist system. ${ }^{49}$

Actively connecting their protests for rights and recognition with protest movements throughout the world for a more equitable international order, the protestors link their rights claims to the (re)production of fundamental inequalities in the international system. But the protestors not only claim that the global North plays a significant role in the (re)production of this system and therefore in their predicament, but that the North's implication in these processes produces a responsibility to provide rights protection, rather than reserving such protection only for those whose circumstances of flight are covered by currently existing 
international protection instruments. In response to a wave of deportations in December 2013, the protestors in Austria issued a statement in which they called upon all members of the global North to recognise and act on this responsibility:

There are a lot of different problems and threats from which people are fleeing. So-called 'democratic' western countries actively produce reasons to flee by destroying other countries through wars, economic exploitation and supporting authoritarian and murderous regimes. Everyone in the 'western world' is responsible for not looking away and showing solidarity $!^{50}$

The broader point being made by the protestors, then, is not simply that many of them come from states which cannot guarantee protection of their human rights, although this is, of course, also true..$^{51}$ It is, rather, that the political, economic, and social structures of the international system play a crucial role in preventing the enjoyment of human rights in many states, that this precipitates forced migration, and that, if the international community takes human rights as seriously as it claims to, then the protestors' entitlement to their human rights must be recognised, and protection of those rights provided. The protestors argue that access to the system of surrogate rights protection that the refugee regime provides, since it is the only such system currently existing, should not be limited only to those who can meet the restrictive definition of a Refugee in the 1951 Convention. This is not to claim that all migrants are refugees and, thus, to dispense with the category, or meaning, of 'refugee' altogether. It is, rather, to draw attention to the restrictive nature of Refugee status and the way in which access to international rights protection is not based upon the lack of rights protection itself but upon an individual's ability to show that the reason they lack rights protection is a reason currently recognised in the Refugee Convention. ${ }^{52}$ But, more than this, the protestors also claim that the international community must address the structural issues that cause forced migration. In other words, they must recognise the entitlement to a social and international order in which the realisation of rights is possible, and begin to work toward it. 
Within the forced migration literature it is becoming the norm to recognise that strictly 'internalist' explanations of forced migration are inadequate and that focus must also be placed on 'externalist' causes ${ }^{53}$ but the internalist paradigm still holds a powerful grip on many theorists and policy-makers. Nevertheless, the connections that the protestors highlight between these conditions, outside actors, and forced migration, have been recognised in the past, most notably by the United Nations. In 1981, for example, the Special Rapporteur appointed by the Chairman of the Commission on Human Rights to study the question of human rights and mass exoduses submitted a report stating that:

\footnotetext{
It is abundantly clear that unless ways can be found to counteract the withholding of, or outright violations of, human rights, unless there is a more equitable sharing of the world's resources, more restraint and tolerance, the granting to everyone [...] the right to belong or alternatively to move in an orderly fashion to seek work, decent living conditions and freedom from strife - the world will continue to have to live with the problem of mass exodus. $^{54}$
}

At the same time, the General Assembly had appointed a Group of Governmental Experts on International Co-Operation to Avert New Flows of Refugees, which found that economic and social factors that threaten physical integrity and survival are not only a cause of past migrations (and were predicted to be a cause of future migrations), but that, in a number of developing states, "they are generally the result of the prolongation of the state of underdevelopment inherited from colonialism and aggravated by a difficult economic environment." $" 55$

Returning to Pogge's explanation of Article 28, and what it appears to require, the similarities with the broader claims and demands that the protestors make become clearer. To bring about a social and international order in which human rights can be fully realised requires that fundamental institutional reforms at the social and international levels be supported and worked toward and that, while this process develops, the victims of such systemic injustice are 
shielded from the harms that the system produces. The protestors' broader claims and demands are claims, fundamentally, for such long-term reforms, and their more immediate demands those that can be accommodated within the refugee regime - can be understood as demands, in the short-term, to the shields of which Pogge speaks. The refugee regime, and its accompanying legal status of Refugee, is the only currently existing system of surrogate rights protection - or shield - for those forced to flee their homes. Understanding the protestors' claims and demands as Article 28 rights claims provides a powerful argument that they can and should be entitled to this system of surrogate protection, while the structural obstacles of the current order to human rights fulfilment globally are addressed. ${ }^{56}$ But engaging with these claims and demands is, fundamentally, a question of responsibility, and it is to this question that this paper now turns.

\section{Political Responsibility for Structural Injustice}

None of the accounts of responsibility for refugees outlined in section one seem adequate to work through the challenging questions raised by the protestors. As has been shown, the protestors have much more to say about the nexus between human rights, injustice, and forced migration than traditional theories of responsibility for refugees, which take the state as the starting point, isolate the relationship between the state and the forced migrant from the surrounding structural context, and reduce the complexity of the forced migrant's search for rights protection to the asylum claim. Therefore, it may be more helpful to turn to a conceptualisation of responsibility which is, on the surface, unrelated to the experience of forced migration: Iris Marion Young's understanding of political responsibility for structural injustice.

\section{Structural injustice and responsibility}

Structural injustice is a particular kind of injustice which presents intellectual and practical 
challenges. Structural injustice differs from the wrongful action of a particular individual agent. It exists when

social processes [themselves the creation of a multitude of past and present actors, rather than any single actor] put large categories of persons under a systematic threat of domination or deprivation of the means to develop and exercise their capacities, at the same time as these processes enable others to dominate or have a wide range of opportunities for developing and exercising their capacities. ${ }^{57}$

Rather than being the outcome of any one individual action, structural injustice occurs as a consequence of "many individuals and institutions acting in pursuit of their particular goals or interests, within given institutional rules and accepted norms." ${ }^{.58}$ All the actors who actively participate in the ongoing schemes of cooperation that constitute these structures are responsible for them, in the sense that they are part of the process that causes them. But, importantly, they are not responsible in the sense of having directed the process or intended its outcomes. ${ }^{59}$ Young differentiates her model of political responsibility for structural injustice from what she refers to as the liability model - of legal systems and much normative political theory - which appears to require that a direct relationship be traced between the action of an identifiable person or group and a specific harm in order to assign blame or guilt, and from which redress or punishment would follow. With structural injustice, however, "it is often not possible to trace which specific actions of which specific agents cause which specific parts of the structural processes and their outcomes," $" 60$ and so another way to conceptualise responsibility is needed. Young's model consists of five features which distinguish it from the liability model.

First, whereas a liability model seeks to isolate some responsible parties so as to absolve others, the identification of responsibility under the political responsibility model does not. There may be instances when singling out a single state, or other entity, as liable for a particular wrong is both possible and desirable, and in such cases the liability model should be applied, 
but when harms result from the participation of a great many individuals and collectives in institutions and practices which produce injustice, such an isolating model of responsibility is inadequate on its own to address these harms. Second, under the liability model, harms that deviate from normal or acceptable social/legal/political procedures are those for which responsibility is assigned, whereas under the political responsibility model it is precisely these background conditions that are brought into question. Third, although any attribution of responsibility carries multiple temporalities - no model is entirely backward- or forwardlooking - there is a difference in temporal emphasis between the liability and political models. The injustices that social structures produce have not reached some end-point in their development, but are on-going, and so intervention is needed moving forward in order to change them. The point of political responsibility for structural injustice is not strictly, therefore, to compensate for the past, but for all who contribute to the ongoing processes that produce injustice to work to transform these processes into the future. ${ }^{61}$ Fourth, political responsibility is, fundamentally, a shared responsibility. An agent shares political responsibility with others whose actions contribute to the structural processes that produce injustice. It is a responsibility that an agent may personally bear, but they bear it alongside many others who bear it also. If forward-looking responsibility consists in changing the institutions and processes that lead to unjust outcomes in the hope of producing outcomes that are less unjust moving forward, then no one actor can do this alone, and so this shared responsibility requires collective action in order to be discharged effectively. ${ }^{62}$ Finally, in distinction to a duty, political responsibility is relatively open with regard to the actions that count as taking up responsibility, allowing for judgment by different actors according to what the responsibilities are for, the capabilities of agents, and the content of action: different actors can discharge their responsibilities in different ways and, contra Pogge, the bearing of this responsibility is not dependent upon one's citizenship but one's relationship to the structural 
processes producing injustice. ${ }^{63}$ While all five aspects of this model resonate with the protestors' claims and demands as Article 28 rights claims, there are three aspects in particular worth highlighting: the shared nature of such responsibility, its focus on structures and processes, and its forward-looking orientation.

In contrast to the liability model of responsibility, which seeks to isolate specific actors who bear responsibility rooted in concrete past actions so as to absolve others, the political model is essentially shared. Neither forced migration, nor the inequalities and injustices which result from the structures of the international system, are caused by one, or even a handful, of readily identifiable actors; nor can distinct causal chains between specific actions and specific outcomes necessarily be traced. Where such connections can be traced, the liability model such as Souter's conception of asylum as reparation for past injustice ${ }^{64}$ - may well be more appropriate and should be pursued. The political responsibility model is not a replacement for the liability model, but tracing such connections will often not be possible. Rather than giving up on the concept of responsibility entirely due to such complexities, Young posits that responsibility is shared by all those who are in some way involved in the structural processes that produce injustice (including one's state of origin). ${ }^{65}$ Young, thus, argues for a 'two-tiered' approach to thinking about responsibility: our responsibility for specific actions or omissions that have resulted in harm to identifiable others (liability), and our on-going responsibility to address unjust structures (political). Returning to the responsibility claims made by the protestors reveals such an understanding of responsibility at work. At first glance their claims may appear only to draw on a liability model: the North bears responsibility because of their implication in the production of the conditions from which the protestors have fled. However, the protestors also speak of "structures", "networks", "orders", "circuits", and "mutual relations". They connect their struggle with the struggle of others fighting for a more just and equitable international system, and situate the problem of forced migration within a broader 
human rights discourse, revealing not only an understanding of the complexity of global structural processes which belies a simplistic approach to the question of responsibility, but also a broader understanding of the problem in need of our attention: it is not just about asylum, but about the fact that the international system as it currently exists cannot assure human rights for everyone, and needs reforming. This would indicate that the protestors' own states origin, the states of the global North, but also the institutions of the global financial system, for example, could be understood as contributing to the perpetuation of the unjust structures and, thereby, bear some responsibility toward addressing them.

The protestors' claims also resonate strongly with the forward-looking nature of political responsibility. The primary purpose of political responsibility is not, strictly, to redress past wrongs, but to intervene moving forward in the processes that produce unjust outcomes: we have this responsibility, Young explains, "always now, in relation to current events and in relation to their future consequences." ${ }^{\prime 66}$ Poverty, dictatorship, oppression, and war are complex processes which are often not caused by any one actor, and hence are shared, but are also processes that have not reached some end-point. They are on-going and will continue absent any meaningful action moving forward, and it is in taking this action that shared responsibility can be discharged. The focus that the protestors place on the structures of international politics and global economics - the social and international order to which Article 28 refers - and the connections they make between their struggle and the struggles of others, indicate a belief that these structures, and the injustices they cause, are likely to continue absent intervention. Demanding respect of their human rights, and appealing to the broader human rights framework also indicates that responsibility for addressing their lack of rights protection, and the complex causes of it, can perhaps be grounded in the human rights project itself. After all, the provision and protection of human rights is itself also an on-going process, which does not end with their codification on paper. They must actively and continually be worked toward, 
protected, and enacted in everyday life. This too, is an on-going project, and one to which the majority of states have formally pledged themselves. And so, while the global North, or "the western world", bears a responsibility, in part, for its past actions, it also bears a shared responsibility moving forward: a responsibility to make, in line with Article 28, meaningful changes in the structures of the international system to enable the realisation of human rights globally. These changes, and the responsibility to make them, can be grounded in the human rights project to which the global North, as the protestors in Germany point out, has freely committed itself, and the recognition that the domestic provision of human rights is never solely in the hands of any one state. But there is one further aspect of the shared nature of political responsibility that warrants attention before concluding: that it can only be discharged effectively through collective action, in which solidarity (and its cultivation) plays a crucial role, but also presents a distinct challenge.

\section{Solidarity, acknowledgement, and political responsibility}

That this shared responsibility can only be taken up effectively through collective action is what makes political responsibility for structural injustice political, and it is here that Young owes her greatest debt to Hannah Arendt. Rather than the work of professional politicians, or the infrequent act of voting, politics is, both for Young and Arendt, action in common - by diverse individuals, in pursuit of a common goal. It is a collective activity - an activity which constitutes a collective through its very exercise - through which individuals take responsibility for the world and their (our) mutually inter-dependent existence within it. It may be that collective action can, in some cases, best be organised by means of state institutions, but in many other cases such action can be taken independently of them. Indeed, alongside the protests of asylum seekers in Europe has been an explosion of local initiatives not mediated by the state in which individuals from all walks of life come together to address not only the 
concrete problems that refugees and asylum seekers face but also to protest and mobilise against the same restrictive policies that are the focus of the asylum seekers' protests. It may certainly be true that without state action individuals can only go so far in tackling structural injustice, ${ }^{67}$ but it is also true that the most powerful agents within any given social structure will often have a vested interest in maintaining the status quo. And so it is often necessary to exert pressure on them to move them to act and to guard against superficial action on their part. ${ }^{68}$ Political responsibility for structural injustice is, then, in essence, a responsibility to be political in relation to structural injustice. It is here that the protestors' call to the people of Austria, Germany, the EU, and "the western world" takes on particular salience: "You are citizens who support our demands. Therefore, why don't you demand that your political representatives - who you, as citizens, have elected - change this unbearable situation?!"69 "Everyone in the "western world" is responsible for not looking away and showing solidarity!"70

This invocation of solidarity is central to the collective action necessary to address structural injustice. Solidarity, for Arendt, is the principle that ought to motivate political action. It does not rely on essentialist and, thus, exclusionary notions of group identity. It is, rather, world-building. It provides a means by which a relationship can be established between people who suffer and people who decide to address this suffering, by establishing a community of interest with the oppressed. ${ }^{71}$ Similarly, for Young solidarity is a relationship among separate and dissimilar actors who decide to stand together, for one another: "unlike brotherhood, which appeals to a natural origin in the unspoken mother, already there to be counted on, solidarity must always be forged and re-forged." 72 Solidarity is necessary precisely because political responsibility does not derive from or depend upon membership in a particular social, ethnic, racial, national group or class. Tackling structural injustice requires 
the collective action of diverse and differentially situated individuals and groups in pursuit of the common goal of creating more just structures.

However, the responsibility to be political, to organise collectively to intervene in unjust processes so as to reform them moving forward, requires that agentss recognise the existence of structural injustice, and recognise and reflect upon the role they may, albeit inadvertently, play in it. Young does briefly highlights four strategies used by individuals and institutions to distance themselves from responsibility, even when they may recognise that there are structural injustices, ${ }^{73}$ but in focusing on strategies of avoidance after recognising structural injustice, Young overlooked the primary problem of recognition itself: the problem that actually assuming responsibility for structural injustice requires that individuals and groups first acknowledge and experience their implication in it. Recognising, and responding, to structural injustice is a problem precisely because of the nature of structural injustice itself: it is "so pervasive, so quotidian, that our connections to it tend to pass unnoticed". ${ }^{74}$ Schiff addresses the problem of recognition and responsiveness by focusing on "crises" which, because they tend to disrupt our experiences of the ordinary, can draw our attention productively back to those experiences, concentrating our attention on structural processes and our role in perpetuating them. ${ }^{75}$ The protests of asylum seekers and refugees in Europe can be seen to play a similar role in relation to enabling the recognition of, and responsiveness to, the structural injustice that precipitates forced migration. Social/political change not only requires engaging in public discussions that reflect on the working of structural processes and publicising the harms experienced by those who these processes and structures disadvantage. It requires, first, taking special efforts to make a break in these processes.$^{76}$ This, arguably, is precisely what the protestors do in taking to the streets and parks of Europe. They make themselves visible and call on the citizens of Austria, Germany, and "the western world" to join them in their struggle for rights and recognition. 
In this way, the protestors also take upon themselves what perhaps might be considered the most controversial aspect of Young's conception of political responsibility for structural injustice: that this shared responsibility, and the collective action necessary to discharge it, also includes the victims of structural injustice. Young argues that their social positions offer victims of injustice a unique understanding of the nature of the problems in need of attention and intervention, and the likely effects of policies and actions proposed by others situated in more powerful and privileged positions. ${ }^{77}$ Interestingly, the protestors themselves appear to recognise that they too share this responsibility: "[ $[\mathrm{t}] \mathrm{o}$ bring this inhuman system to an end, and to stop deportations, we have to organise and to take to the streets. We have to put pressure on those in power, but at the same time get active ourselves. We are all responsible."78

\section{Conclusion}

The claims, demands and the questions of responsibility, raised by these protestors are uncomfortable ones, with no simple answers, and raise numerous practical questions and challenges. But the fact that such claims and demands are uncomfortable and complicated to work through and address is not a reason to dismiss them outright. This article has attempted to engage with them, and has argued that these claims and demands can usefully be understood as Article 28 rights claims - as claims to a social and international order in which human rights can be fully realised. Putting forward Iris Marion Young's model of political responsibility for structural injustice, this article has argued that the shared nature of this responsibility, its focus on structures and processes, and its forward-looking orientation, provide a promising framework within which to begin to engage with the claims and demands beyond asylum - for rights, recognition, and of responsibility - of the protestors. As such, this article is only a starting point, not a blueprint for concrete actions. Indeed, to provide such a blueprint would go against the grain of Young's conceptualisation of political responsibility and the importance 
it places on reflecting on one's own potential position, role, and capabilities in relation to the continued (re)production of structural injustice, and debating and working with others on how best to respond, on the basis of these positions, roles, and capabilities.

The wager of this article, thus, has been that there is much to be gained in terms of understanding the issues at stake in the protection of the human rights of forced migrants if these issues are placed back within a larger structural context; if the position, and voices, of forced migrants themselves is taken as the starting point; and if broader issues of human rights are put centre stage. As the analysis above demonstrates, the protesting refugees and asylum seekers in Germany and Austria do far more than make a claim for physical asylum necessitated by an unwillingness of their state of origin to protect their human rights. The connections that they make between the politico-economic situations in their countries of origin, and the economic and political structures of the international system presents a challenge to move beyond a narrow root causes approach to forced migration, which often aims simply to contain it, and toward a more honest reckoning the geopolitical, economic and developmental challenges that generate it. ${ }^{79}$ In drawing attention to the structures and processes that govern the international system, and the ways in which it fails to adequately ensure the protection of their human rights, the protestors also present an important challenge to traditional debates about global responsibilities, positing a wider range of possible responsibility bearers than the state, and thus potentially opening new avenues for reform by engaging with a more diverse group of actors, including ordinary citizens of the global north. Finally, by explicitly asserting themselves as rights-bearers, and, on this basis, claiming a right to the legal status of 'Refugee' when they may not fit the narrow legal definition in the Refugee Convention, they bring into focus the disparity between the need for rights protection and the conditions under which current protection mechanisms are made available. In doing so they reframe the issue of protection of the rights of forced migrants as an unresolved question of justice, and highlight 
the need to take seriously the promise and challenge of Article 28: that everyone is entitled to a social and international order in which the rights and freedoms set forth in the UDHR can be fully realised.

${ }^{1}$ K. McGuaran and K. Hudig, 'Refugee Protests in Europe: fighting for the right to stay', Statewatch Journal: reflections on the State and Civil Liberties in Europe 23:314 (2014): 28

${ }^{2}$ See, for example, A. Gündoğdu, Rightlessness in an Age of Rights: Hannah Arendt and the Contemporary Struggles of Migrants (Oxford: Oxford University Press, 2015); P. Nyers, 'No One is Illegal Between City and Nation', Studies in Social Justice 4:2 (2010): 127-143; P. Nyers, 'Abject Cosmopolitanism: The Politics of Protection in the Anti-Deportation Movement', Third World Quarterly 24:6 (2003): 1069-1093.

${ }^{3}$ Redacted for anonymity

${ }^{4}$ Refugee Struggle, 'In Solidarity with our comrade and friend Arash D.', available at (https://refugeestruggle.org/en/article/12th-january-2014-munich), accessed 1 April 2016

${ }^{5}$ United Nations General Assembly, Universal Declaration of Human Rights, UNGA 217/A/III, Art.28

${ }^{6}$ More common is a focus on human trafficking as a form of forced migration. Diana Tietjens Meyers' 'Rethinking Coercion for a World of Poverty and Transnational Migration' in D. T. Meyers (ed.) Poverty, Agency and Human Rights (Oxford: Oxford University Press, 2014) is a notable exception.

${ }^{7}$ For a useful overview of this debate, see V. Chétail, ‘Are Refugee Rights Human Rights? An Unorthodox Questioning of the Relations between Refugee Law and Human Rights Law' in R. Rubio-Marin (ed.) Human Rights and Immigration (Oxford: Oxford University Press, 2014): 1972.

${ }^{8}$ Serena Parekh's recent book, Refugees and the Ethics of Forced Displacement (New York: Routledge, 2017), is a notable and timely exception. 
${ }^{9}$ See, for example, G. Goodwin-Gill, 'Refugees and Responsibility in the $21^{\text {st }}$ Century: More Lessons Learned from the South Pacific', Pacific Rim Law \& Policy 12:1 (2003), pp. 23-47

${ }^{10}$ M. Walzer, Spheres of Justice: A Defence of Pluralism and Equality (New York: Basic Books, 1983): 48-51

${ }^{11}$ D. Miller, National Responsibility and Global Justice (Oxford: Oxford University Press, 2007): 202

${ }^{12}$ See, for example: A. McNevin, Contesting Citizenship: Irregular Migrants and New Frontiers of the Political (New York: Columbia University Press, 2011); E. Isin and P. Nyers, 'Globalizing Citizenship Studies' in E. Isin and P. Nyers (eds.) Routledge Handbook of Global Citizenship Studies (London: Routledge, 2014): 1-11.

${ }^{13}$ A. McNevin, 'Learning to live with irregular migration: towards a more ambitious debate on the politics of "the problem", Citizenship Studies 21:3 (2017): 255-274

${ }^{14}$ McNevin (2011) p.127

${ }^{15}$ E. F. Isin and G. I. Nielsen, 'Introduction' in E. F. Isin and G. I. Nielsen (eds.), Acts of Citizenship (London: Zed Books, 2008), pp.1-12

${ }^{16}$ The following website is a useful resource for an overview of the different groups active in Germany, the actions undertaken, and links to additional resources: http://oplatz.net/

${ }^{17}$ H. Johnson, 'These Fine Lines: locating non-citizenship in political protest in Europe', Citizenship Studies 19:8 (2015), p.952

${ }^{18}$ L. Linke, 'This is our battleground: How a new refugee movement is challenging Germany's racist asylum laws', Ceasefire Magazine (2013), available at (https://ceasefiremagazine.co.uk/thisbattleground-germanys-refugee-movement-challenges-racist-asylum-laws/), accessed 2 March 2017

${ }^{19}$ M. Grzinic, 'A Refugee Protest Camp in Vienna and the European Union's Processes of Racialization, Seclusion, and Discrimination', e-Flux Journal 43 (2013), pp.1-2

${ }^{20}$ Refugee Protest Camp Vienna, 'Urgent Demands', available at (http://www.refugeecampvienna.noblogs.org/post/2012/11/25/urgent-demands), accessed 31 March 2017 
${ }^{21}$ Refugee Protest Camp Vienna, 'Concretized Demands', available at (http://www.refugeecampvienna.noblogs.org/demands/demands-made-concrete), accessed 31 March 2017

${ }^{22}$ Refugee Struggle, 'In Solidarity with our comrade and friend Arash D.', available at (https://refugeestruggle.org/en/article/12th-january-2014-munich), accessed 1 April 2017

${ }^{23}$ A detailed timeline, with links to press releases and videos of key events in the protest can be accessed via: https://refugeecampvienna.noblogs.org/timeline/

${ }^{24}$ Johnson (2015) p.960

${ }^{25}$ Refugee Struggle, 'In Solidarity with our comrade and friend Arash D.', available at (https://refugeestruggle.org/en/article/12th-january-2014-munich), accessed 1 April 2017

${ }^{26}$ M. Lloyd, 'Performing Radical Democracy', in A. Little and M. Lloyd (eds.), The Politics of Radical Democracy (Oxford: Oxford University Press, 2008), pp.36-37

${ }^{27}$ United Nations, 'Convention relating to the Status of Refugees', United Nations Treaty Series 189:2545 (1951), Art.1A(2)

${ }^{28}$ European Union, 'Directive 2011/95/EU of the European Parliament and of the Council of 13 December 2011 - "Qualification Directive”, European Union Official Journal 337:9 (2011), Art.15

${ }^{29}$ J. C. Hathaway and M. Foster, The Law of Refugee Status (2 ${ }^{\text {nd }}$ Edition) (Cambridge: Cambridge University Press, 2014). See also: M. Foster, International Refugee Law and Socio-Economic Rights: Refuge from Deprivation (Cambridge: Cambridge University Press, 2007), p.3, p.348

${ }^{30}$ A recent UNHCR report on the provision of asylum in the EU has shown how much of a lottery recognition under EU-specific rules has turned out to be in practice: UNHCR, Asylum in the European Union: A Study of the Implementation of the Qualification Directive, (Brussels, 2007), available at (http://www.refworld.org/docid/473050632.html), accessed 1 September 2016

${ }^{31}$ Transnational human rights obligations is an emerging area of human rights scholarship. See, for example: S. Skogly and M. Gibney, 'Transnational Human Rights Obligations,' Human Rights Quarterly 24:3 (2002): pp.781-798 
${ }^{32}$ C. Malik in W. A. Schabas (ed.) The Universal Declaration of Human Rights: The Travaux Préparatoires: Volume 1 October 1946 to November 1947 (Cambridge: Cambridge University Press, 2013), p.1811

${ }^{33}$ J. Curtis and S. Darcy, 'The Right to a Social and International Order for the Realization of Human Rights: Article 28 of the Universal Declaration and international cooperation' in D. Keane and Y. McDermott (eds.), The Challenge of Human Rights: Past, Present and Future (Cheltenham: Edward Elgar Publishing, 2012), pp.12-13

${ }^{34}$ United Nations, 'International Covenant on Civil and Political Rights', United Nations Treaty Series 999:14669 (1966) and United Nations, 'International Covenant on Economic, Social and Cultural Rights', United Nations Treaty Series 993:14531 (1966), Art.2(1)

${ }^{35}$ United Nations General Assembly, Declaration on the Right to Development, A/RES/41/128

${ }^{36}$ United Nations Committee on Economic, Social and Cultural Rights, Substantive Issues Arising in the Implementation of the International Covenant on Economic, Social and Cultural Rights: Poverty and the International Covenant on Economic, Social and Cultural Rights: Statement adopted by the Committee on Economic, Social and Cultural Rights, E/C.12/2001/10 (4 May 2001)

${ }^{37}$ T. Pogge, 'Human Rights and Human Responsibilities', in A. Kuper (ed.), Global Responsibilities: Who Must Deliver on Human Rights? (London: Routledge, 2005), p.14

${ }^{38}$ Ibid, p. 15

${ }^{39}$ Ibid.

${ }^{40}$ Ibid, p. 18

${ }^{41}$ Ibid

${ }^{42}$ S. Marks, 'Foreword', in M. E. Salomon, Global Responsibility for Human Rights: World Poverty and the Development of International Law (Oxford: Oxford University Press, 2007), p.x

${ }^{43}$ M. Risse, 'How Does the Global Order Harm the Poor?' Philosophy \& Public Affairs 33:4 (2005), pp.349-376. See also, D. Miller, 'National Responsibility and Global Justice', Critical Review of International Social and Political Philosophy 11:4 (2008), pp.383-399 
${ }^{44}$ T. Pogge, World Poverty and Human Rights: Cosmopolitan Responsibilities and Reforms (Cambridge: Polity Press, 2005) p.21

${ }^{45}$ D. Satz, 'What Do We Owe the Global Poor'? Ethics and International Affairs 19:1 (2005), p.51

${ }^{46}$ Pogge, 'Human Rights and Human Responsibilities' p.15

${ }^{47}$ S. Castles, 'The Migration-Asylum Nexus and Regional Approaches' in S. Kneebone and F. Rawlings-Sanaei (eds.), New Regionalism and Asylum Seekers: Challenges Ahead (New York: Berghahn Books, 2007): 25-42

${ }^{48}$ Refugee Struggle, 'In Solidarity with our comrade and friend Arash D.', available at (https://refugeestruggle.org/en/article/12th-january-2014-munich), accessed 1 April 2017

${ }^{49}$ Refugee Tent Action Berlin, 'Why We Marched to Berlin and Why We Continue Our Resistance', available at (http://thecaravan.org/node/3619) accessed 1 April 2017

${ }^{50}$ Refugee Protest Camp Vienna, 'New wave of deportations from Austria - get active for concrete solidarity to stop deportations', available at (https://refugeecampvienna.noblogs.org/post/2013/12/14/new-wave-of-deportations-from-austriaget-active-for-concrete-solidarity-to-stop-deportations/), accessed 1 April 2017

${ }^{51}$ The majority of the protestors in Austria and Germany come from Pakistan, Iran, Afghanistan, Somalia and Sudan.

${ }^{52}$ This is an understanding more in line with pre-1951 definitions of Refugee status which were not premised upon the ability to demonstrate persecution for one of the five grounds in the 1951 Convention but on the absence (de jure or de facto) of state protection of rights. This is not to say that just because such an understanding pre-dates the 1951 Convention that it is therefore 'correct'. It is merely to highlight the fact that the 1951 Convention definition is the result of political deliberations and decisions - decisions taken deliberately to reduce the scope of state responsibilities, in full knowledge of the millions of people in need of protection to whom it would not apply - rather than a reflection of a supposed 'essence' of refugeehood and its relation to human rights. See: Hathaway and Foster (2007) pp.17-20

${ }^{53}$ B. S. Chimni, 'The Geopolitics of Refugee Studies: A View from the South', Journal of Refugee Studies 11:4 (1998), pp.350-374. 
${ }^{54}$ S. Aga Khan, Study on Human Rights and Massive Exoduses (31 December 1981), E/CN.4/1503

${ }^{55}$ United Nations General Assembly, International Co-operation to Avert New Flows of Refugees: Note by the Secretary-General (13 May 1986), A/41/324: §39

${ }^{56}$ While there are forced migration scholars and political theorists who recognise that the definition of a Refugee should be expanded to include a wider range of people forced to flee their homes (see, for example, A. Betts, 'Survival Migration: A New Protection Framework', Global Governance 16:3 (2010): $361-382$ ), attention is rarely paid to the simultaneous need to engage in the longerterm reform efforts which may prevent the need to migrate in search of human rights fulfilment.

${ }^{57}$ I. M. Young, "Responsibility and Global Justice: A Social Connection Model”, Social Philosophy and Policy 23(1) (2006), p.114

${ }^{58}$ Ibid

${ }^{59}$ Ibid

${ }^{60}$ Ibid, p.115 (emphasis added)

${ }^{61}$ Ibid, p. 122

${ }^{62}$ Young (2006) p.123

${ }^{63}$ I. M. Young, "Political Responsibility and Structural Injustice" presented as the Lindley Lecture, University of Kansas (5 May 2003), p.13

${ }^{64}$ J. Souter, 'Towards a Theory of Asylum as Reparation for Past Injustice', Political Studies 62:2 (2014), pp.326-342

${ }^{65}$ Responsibility being shared does not, however, mean that we can parcel up that responsibility and assign a calculable portion of it to each actor, as that process would also rely on the isolation of causal chains.

${ }^{66}$ I. M. Young, Responsibility for Justice (New York: Oxford University Press, 2011), p.92

${ }^{67}$ S. Parekh, 'Getting to the Root of Gender Inequality: Structural Injustice and Political Responsibility', Hypatia 26:4 (2011), p.683

${ }^{68}$ Young (2006) p.127

${ }^{69}$ Grzinic (2013) p.3 
${ }^{70}$ Refugee Protest Camp Vienna, 'New wave of deportations from Austria - get active for concrete solidarity to stop deportations', available at (https://refugeecampvienna.noblogs.org/post/2013/12/14/new-wave-of-deportations-from-austriaget-active-for-concrete-solidarity-to-stop-deportations/), accessed 1 April 2017

${ }^{71}$ K. Reshaur, 'Concepts of Solidarity in the Political Theory of Hannah Arendt', Canadian Journal of Political Science 25:4 (1992), p.724

${ }^{72}$ Young (2011) p. 120

${ }^{73}$ These four strategies are: reification; denying connection; hiding behind the demands of the immediate and everyday; and the "It's not my job" position - when individuals recognise that structural injustice exists, but argue that it is the responsibility of governments and international institutions to address, since they are best placed to do so. See, Young (2011) pp.153-170. For an overview of strengths and weaknesses of Young's work on structural injustice, see Risse's review of Young's Responsibility for Justice, available at: http://www.ndpr.nd.edu/news/responsibilityfor-justice/

${ }^{74}$ J. L. Schiff, Burdens of Political Responsibility: Narrative and the Cultivation of Responsiveness (New York: Cambridge University Press, 2014), p.28

${ }^{75}$ Ibid

${ }^{76}$ Young (2011) p. 150

${ }^{77}$ Ibid p.113

${ }^{78}$ Refugee Protest Camp Vienna, 'New wave of deportations from Austria - get active for concrete solidarity to stop deportations', available at (https://refugeecampvienna.noblogs.org/post/2013/12/14/new-wave-of-deportations-from-austriaget-active-for-concrete-solidarity-to-stop-deportations/), accessed 1 April 2017

${ }^{79} \mathrm{McNevin}$ (2017) p.265 